\title{
Seismic Behavior Evaluation of URM Building in Rural Area
}

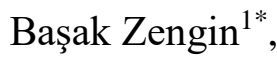 \\ 1* Kahramanmaraş Istiklal Univeristy, Elbistan Vocational High School, Kahramanmaraş, Turkey, (ORCID: 0000-0003-3719-9423), \\ zenginbasak@gmail.com
}

(First received 13 May 2021 and in final form 4 August 2021)

(DOI: 10.31590/ejosat.936853)

ATIF/REFERENCE: Zengin, B. (2021). Seismic Behavior Evaluation of URM Building in Rural Area. Avrupa Bilim ve Teknoloji Dergisi, (25), 607-614.

\begin{abstract}
Approximately 30\% of Turkey's population lives in rural areas and they are seated in structures, which called unreinforced masonry building (URM). These types of buildings consist of mudbrick structures with wooden carcasses, masonry-adobe structures with wooden supports, and brick and briquette masonry structures supported by reinforced concrete lintels. The construction of masonry structures is easy and low cost because of the easy availability of building materials such as brick and masonry, so it is frequently preferred.

However, these buildings, especially poorly constructed masonry buildings in many respects, have performed very badly in recent earthquakes, causing loss of life and property.

For this reason, it was once again seen that the demand for the improvement or strengthening of these structures is very important in terms of saving life and property, and that seismic research and evaluation are necessary for this purpose. In this study, the earthquake behavior of the brick masonry structure with a flexible diaphragm is evaluated using SAP2000 Finite element program. Two types of masonry buildings were modelled which are plain and bond beams. Displacement, Base shear, and Stress data The analysis results are obtained and compared for two models.
\end{abstract}

Keywords: Earthquake, Brick masonry building, Seismic evaluation.

\section{Kırsal Alanda URM Binasının Deprem Davranışı Değerlendirmesi}

Öz

Türkiye nüfusunun yaklaşık \%30'u kırsal kesimde yaşıyor ve donatısız/betonarme olmayan yığma bina (URM) olarak adlandırılan yapılarda yaşamaktadırlar. Bu tip binalar, ahşap karkaslı kerpiç yapılar, ahşap destekli yığma-kerpiç yapılar ve betonarme lentolarla desteklenen tuğla ve briket yığma yapılardan oluşmaktadır. Yığma yapıların yapımı, tuğla ve yığma gibi yapı malzemelerinin kolay bulunabilirliği nedeniyle kolay ve düşük maliyetli olduğundan yaygın olarak rastlanmaktadır.

Ancak bu binalar, özellikle pek çok açıdan kötü inşa edilmiş yığma binalar, son depremlerde çok kötü performans göstermiş, can ve mal kaybına neden olmuştur.

$\mathrm{Bu}$ nedenle bu yapıların iyileştirilmesi veya güçlendirilmesi talebinin can ve mal kurtarılması açısından çok önemli olduğu ve bu amaçla sismik araştırma ve değerlendirmenin gerekli olduğu bir kez daha görülmüştür. Bu çalışmada esnek diyaframlı tuğla yığma yapının deprem davranışı SAP2000 Sonlu eleman programı kullanılarak değerlendirilmiştir. Düz ve hatıl olmak üzere iki tip yığma bina modellenmiştir. Yer değiştirme, Taban kesme ve Gerilme verileri Analiz sonuçları elde edilmiş ve iki model için karşılaştırılmıştır.

Anahtar Kelimeler: Deprem, Tuğlalı Yığma Yapı, Sismik analiz.

\footnotetext{
* Corresponding Author: zenginbasak@ gmail.com
} 


\section{Introduction}

Masonry is the most common building types adopted throughout the world for the construction of low-medium rise buildings due to thermal insulation, culture and costeffectiveness (Chourasia et al., 2019)

According to research $23.20 \%$ of Turkey's population is living in rural areas (towns and villages), shown in (Table 1). The majority of people living in these regions prefer the masonry structure. In addition, many of the traditional and historical buildings were built as masonry. Masonry structures are preferred because they can be easily made from local materials and are economical (Göker \& Karaşahin, 2015).

The causes of damage in masonry structures are mostly due to the fact that the load-bearing wall is placed on top of each other, the wall element units are not connected to each other with a strong mortar, and the creation of door and window gaps that will disrupt the integrity of the wall. In addition, the reasons such as not forming concrete or wooden continuous beams that are formed along the outer walls and placed on the inner walls, not making the crossing with smooth cut stones at the junction of the two walls formed perpendicularly, making the structure heavier with the soil covered roof flooring and not using a single type of material on the walls of the building are also important. (Sorguç 2000; Göker and Karaşin, 2015).

Table 1. Village and Urban Population of Turkey in 2011 and 2017 (Ceylan \& Somuncu, 2018)

\begin{tabular}{llllll}
\hline \multicolumn{2}{c}{ Village } & \multicolumn{3}{c}{ City } & Total \\
\cline { 1 - 5 } Year & Population & $\%$ & Population & $\%$ & \\
\hline $\mathbf{2 0 1 1}$ & 17.338 .563 & 23,20 & 57.385 .706 & 76,80 & 74.724 .269 \\
\hline $\mathbf{2 0 1 7}$ & 6.049 .393 & 7,48 & 74.761 .132 & 92,52 & 80.810 .525 \\
\hline
\end{tabular}

Turkey is located in the seismic region and the rural housing stock is quite more, that is a fact that can not be ignored. Earthquake damages of rural houses cause great loss of life and property. In order to minimize these losses, emphasis should be placed on strengthening existing rural housing (Korkmaz, 2007).

Today, such structures are widely used in rural areas because they are economical and accommodate themselves according to the current environmental conditions(Sharma \& Khare, 2016; Usta et al., 2017).

Masonry building can withstand the gravity load satisfactorily; however, unreinforced masonry building (URM) has the tendency to collapse in a brittle manner when subjected to earthquake load (Banerjee et al., 2020; Dutta et al., 2015).

The Confined masonry has always gained vital importance in construction applications, as it performs much better than unreinforced masonry and non-ductile reinforced concrete infill structures during seismic loads. The CM buildings are mostly known for the low-rise residences of South America, Central.

America, Asian countries and European countries. Past research has demonstrated satisfactory performance (Gupta \& Singhal, 2020)
Traditional URM buildings are still one of the most representativesample in the building stock of developing countries, even though their low seismic capacity is well known (Furtado et al., 2015; Gautam \& Chaulagain, 2016; Pinar et al., 2018, Losanno et al., 2021)

Unreinforced masonry structures were badly damaged in various earthquakes. Many of these types of structures lived through even large earthquakes. They continue to pose a large seismic risk, not only in a rural areas but also in many parts of the world. In order to reduce casualties and property loss due to damage in masonry buildings in earthquakes, it is necessary to understand the true behavior and response of these buildings in lateral loads which is possible through research and study in this field. Unreinforced masonry structures show highly inelastic behavior. The nonlinear behavior of unreinforced masonry can be determined by conducting either various experiments or structural analysis. The linear static analysis methods are inadequate and inaccurate as they cannot incorporate the nonlinear characteristics of unreinforced masonry. Therefore nonlinear analysis of masonry buildings is preferable for both academics and practicing engineers (Chikanbanjar et al, 2019).

Most importantly, the presence of the vertical and horizontal reinforced concrete element plays an important role in preventing untimely fracture of the masonry and therefore helps in preventing the collapse of a single (or group) masonry panel. In fact, the behavior of a framed masonry wall has slightly greater strength and much greater ductility (ie, the capacity to dissipate energy in the plastic region) than an unconstrained masonry wall. In addition, the reinforced concrete members form a very good connection between in-plane and orthogonal masonry panels so that first mode collapse of walls (i.e. out of plane collapse) is entreated (Nucera et al., 2012) In terms of seismic vulnerability, the collapse of non-engineered and semiengineered constructions had resulted in major losses as a consequence of the seismic event (Losanno et al., 2021).

During the last decades, masonry wall buildings were theoretically analyzed by means of finite element method both linearly and non linearly(Capozucca et al., 2018) In this paper the main objectives is to validate the model of a three-story masonry building with and without beam in SAP2000 software, to perform earthquake analysis by nonlinear time history analysis.

\section{Material and Method}

Two unreinforced masonry buildings of one, two, three-storey brick masonry building are taken for this study. $\mathrm{T}$ flexible types of floors are considered. One consists of a brick masonry wall with a bond beam while the other is a brick masonry wall without a bond beam. Each building is analysed separately. The architectural plan of all the buildings is the same as shown in Figure 1 (a). 3D Finite element model of masonry brick building is modelled using SAP2000 V22, shown in Figure 1 (b).

The first model is without bond beam, with a flexible diaphragm an opening indoor and window with a flexible diaphragm. The other is with bond beams at diaphragm level, lintel level and sill level with flexible diaphragm an opening indoor and window 
with a flexible diaphragm. In addition, reinforcements are provided along the edges and at the door opening.

Three-story brick masonry houses with wall were shaped by SAP 2000 version 21. Both models have the same type $250 \mathrm{~mm}$ masonry thick wall and flexible roof diaphragm. The rectangle shell element was considered for the model of the wall. The shell element can be modelled homogeneous and shell layered, in our study, the layered shell area element is considered in order to obtain full shell behavior.

In the model, the lateral load carry by the shear walls. The Modelling of the Masonry building without and with the bond beam shown in Figure 2. The masonry building was modelled in shell and area, the material of building was chosen brick material, the material properties given in Table 2 .
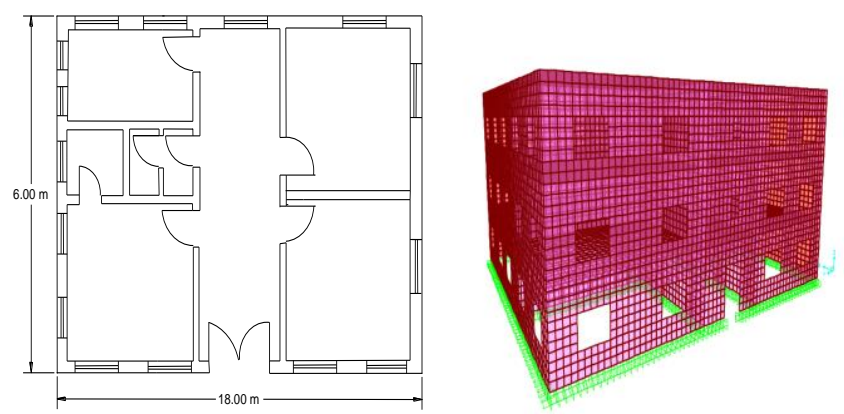

Figure 1. The 3-D model of 3-story Brick Masonry Building
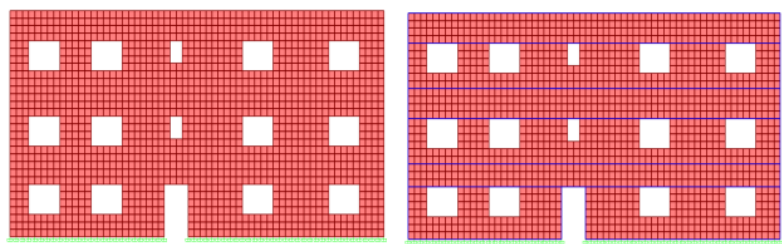

Figure 2. Masonry buildings models with and without a beam

For the reinforcement three-story masonry building, It was used at concrete beam diaphragm, lintel and Sill levels with a size of 250x $150 \mathrm{~mm}$, and Beam Masonry pier was used for Edge and door opening with a size of 250x $250 \mathrm{~mm}$. the Concrete Beam has $12 \mathrm{~mm} \# 2$ nos reinforcement detail at the top and bottom and, while the Beam Masonry pier has $10 \mathrm{~mm} \# 4$ nos. Reinforcement detail (Brijpuriya R. \& Sharma, 2019)

Table 2. Material properties of the masonry (Brijpuriya \& Sharma, 2019)

\begin{tabular}{lllllc}
\hline $\begin{array}{l}\text { Type } \\
\text { material }\end{array}$ & $\begin{array}{l}\text { Compressi } \\
\text { Strength }\end{array}$ & $\begin{array}{l}\text { Modulus } \\
\text { of } \\
\text { Elasticity }\end{array}$ & $\begin{array}{l}\text { Modulus } \\
\text { of } \\
\text { Rigidity }\end{array}$ & $\begin{array}{l}\text { Density } \\
\text { of } \\
\text { masonry }\end{array}$ & $\begin{array}{l}\text { Poisson } \\
\text { of } \\
\text { Ratio }\end{array}$ \\
\hline Isotropc & $2.5 \mathrm{MPa}$ & $1375 \mathrm{MPa}$ & $592.67 \mathrm{MPa}$ & $20 \mathrm{kN} / \mathrm{m}^{3}$ & 0.16 \\
\hline
\end{tabular}

Nonlinear time history analysis is conducted for the assessment of buildings behavior against earthquake loads. For this purpose eleven earthquake data selected from the PEER database. To get an actual response and selecting the ground motion record, the TSC 2018, DD2 target response spectrum was used. Seismic hazard was defined assuming a seismic zone V (highest seismicity level) for a normal building (importance factor $\mathrm{I}=1$ ) on a medium soil, with a peak ground acceleration (PGA) of $0.4 \mathrm{~g}$. Acceleration response spectra corresponding to $5 \%$ equivalent damping. The earthquakes are data shown in Figure 3 and the Characteristic of selected ground motions is shown in Table 3 .

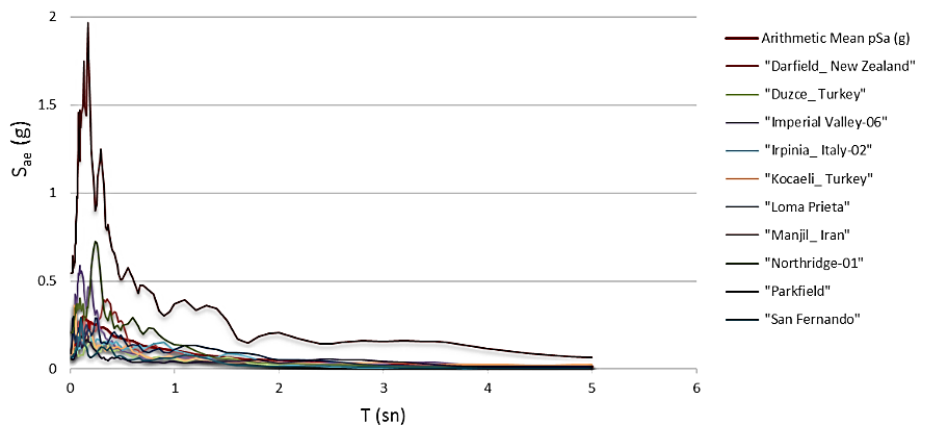

Figure 3. Selected Earthquake data

Table 3. Characteristic of selected ground motions

\begin{tabular}{lllll}
\hline Earthquake Name & Year & Station Name & Magnitude & Mechanism \\
\hline "Darfield_New Zealand" & 2010 & "SPFS" & 7 & Strike slip \\
\hline "Duzce_Turkey" & 1999 & "Lamont 1061" & 7.14 & Strike slip \\
\hline "Imperial Valley-06" & 1979 & "Cerro Prieto" & 6.53 & Strike slip \\
\hline "Irpinia_Italy-02" & 1980 & "Rionero In Vulture" & 6.2 & Normal \\
\hline "Kocaeli_Turkey" & 1999 & "Arcelik" & 7.51 & Strike slip \\
\hline "Loma Prieta" & 1989 & "Coyote Lake Dam- Southwest & 6.93 & Reverse \\
\hline "Manjil_Iran" & 1990 & "Abutment" & 7.37 & Oblique \\
\hline "Northridge-01" & 1994 & "Sunland- Mt Gleason Ave" & 6.69 & Reverse \\
\hline "Parkfield" & 1966 & "Cholame - Shandon Array \#12" & 6.19 & Strike slip \\
\hline "San Fernando" & 1971 & "Santa Felita Dam (Outlet)" & 6.61 & Reverse \\
\hline
\end{tabular}




\section{Result of Time History Analysis}

It is concluded that the brick masonry building with bond beam may have significant effects on the seismic response of the masonry structures, therefore, this type of buildings need to be considered during the design and analysis of the building Nonlinear time history analysis was applied to evaluate the seismic performance of the Brick masonry houses with and without bond beam. The eleven earthquake data were used during the analysis and the results are compared and shown in the form of graphs. The Periods of the Brick Masonry Model is shown in Figure 4.

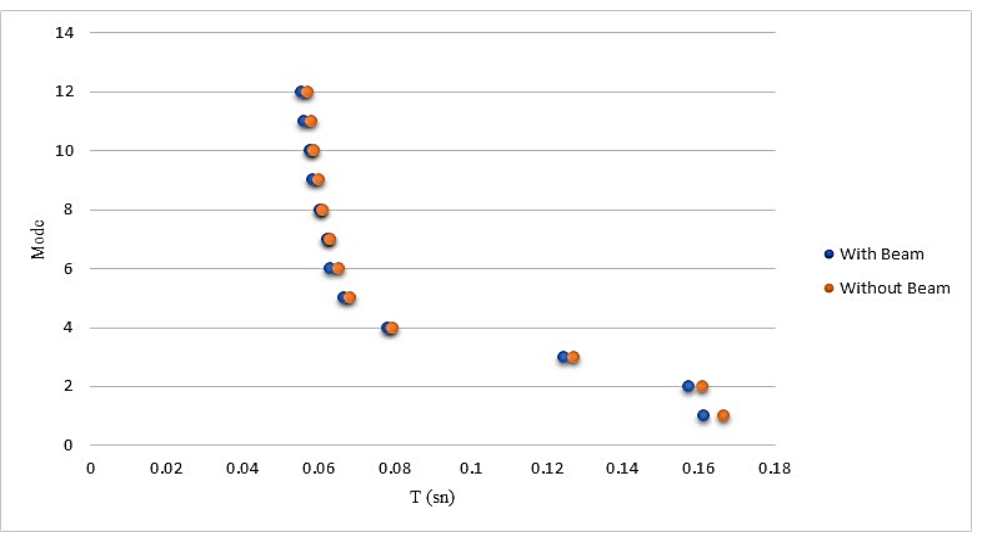

Figure 4. Periods of Brick Masonry Model

For the model without beam, The first period is approximately 0.167 and the period is $1.161 \mathrm{sec}$. For the model with beam, The first period is approximately 0.161 seconds which is very close to the second mode $0.157 \mathrm{sec}$ due to the almost symmetric plan those corresponds to a bending mode shape on both orthogonal horizontal planes. Mode 3 involves shear and torsional movements. Mode 1 and mode 2 are predominant translation modes that exhibit a high relative modal mass in both orthogonal direction and little or near zero in rotation (Sayg1l, 2020) Figure 5 and Figure 6 shows the maximum principal stresses in the structure walls The stresses were determined from an SAP 2000 analysis with earthquake loads. The contour of S11, S22 and S12 stress the first three modes shapes of both models.

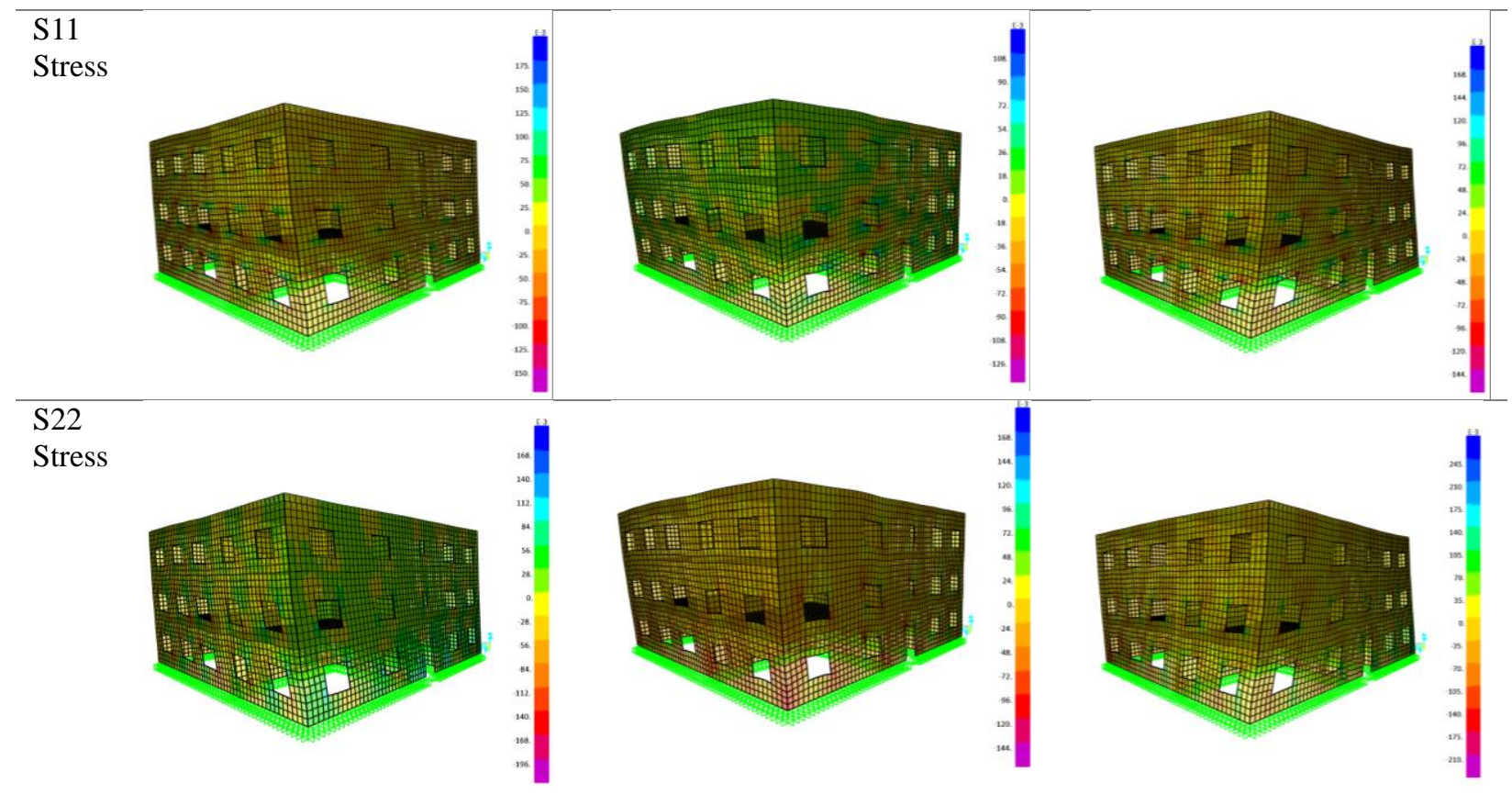




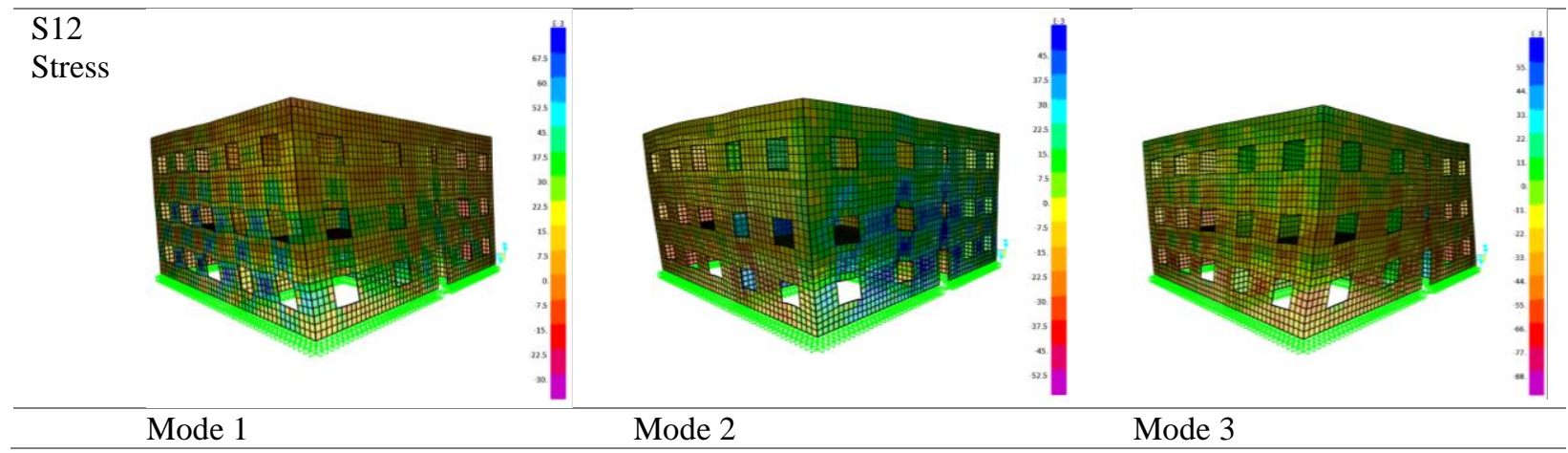

Figure 5. Stress values For the without Beam Model

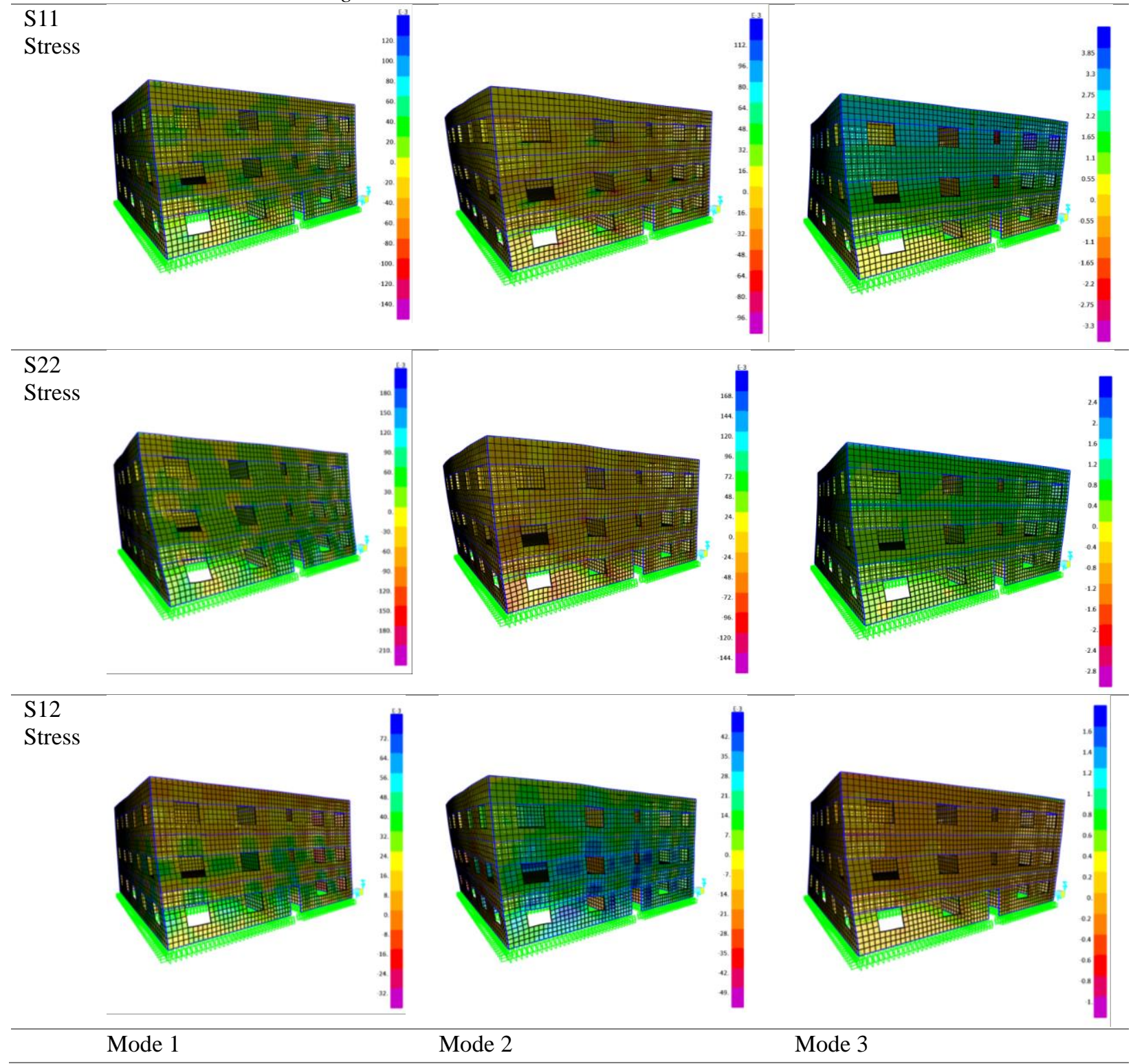

Figure 6. Stress values For the with Beam Model

The considered loads, in this case, is the building self-weights. In Figure 5 and Figure 6; the S11, S22 and S12 stresses reached at one of the surfaces of the shell elements are reported; it should be noted that the maximum value of stress, localized at the lower level. High concentrations of stress can also be found at the corners, windows or openings. It is worth underlining that the color map in Figure 4 has been drawn taking different limits as $\mathrm{MPa}$, that is the design value of the compressive masonry strength obtained using a confidence factor (FC) equal to 2.5 Mpa as the highest absolute value in the color scale. As seen from Figure 5 and Figure 6, most part of the structure remains under compression within permissible limits. Herefore the wall that is around the openings and lower levels should not crack in diagonal tension. There are regions of very high stress located at 
the corners of the piers. These stresses are much greater than the tensile strength of the masonry, therefore the model is likely to crack in these regions. These types of cracks are consistent with the rocking of the structure. The majority of the masonry wall has stresses lower. Across the around the openings there is high stress which means it does not each the diagonal tension strength of the masonry.
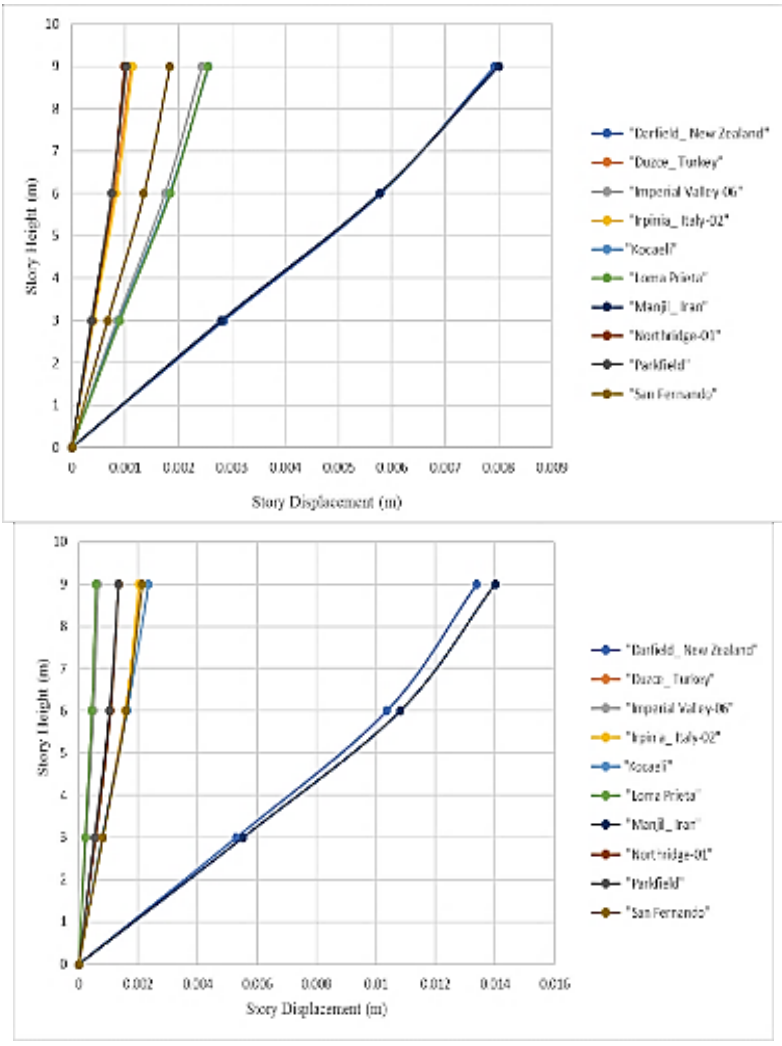

Figure 7. Story Displacements in without Beam model

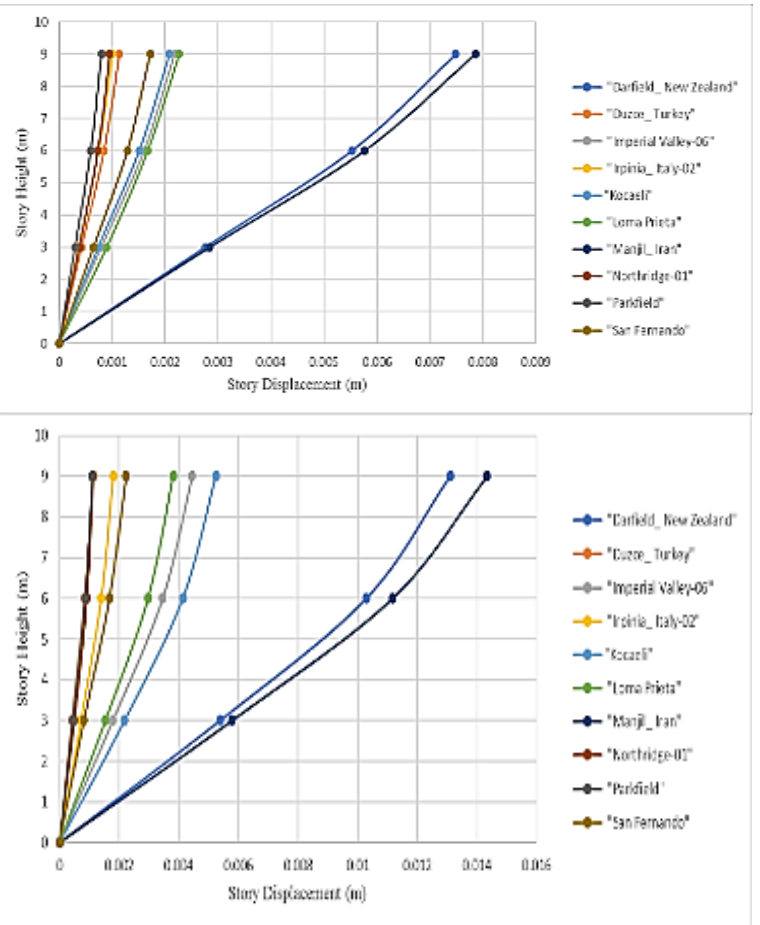

Figure 8. Story Displacements in with Beam model
Figure 7 and Figure 8 shows the relationship between displacements versus storey level. The difference between displacements of bottom and top storey of Brick Masonry model in $\mathrm{X}$ and $\mathrm{Y}$ direction. The maximum story displacement occurred "Manjil Iran" and "Darfield New Zealand" earthquake, respectively. The earthquakes that give the maximum displacement value in the two models and two directions are the same. When the displacement values obtained from the beamed and non-beam masonry models are compared, there is a decrease in the floor displacements when beams are added to the masonry model. Story displacement is more in the model without bond beam as compared to the model with the bond beam. Also, Story drift is maximum for the first model which is without a beam as compared to the model with the bond beam. Based on the story displacement observed in both models, we can say that the model with a bond beam has less displacement than the model without a bond beam.

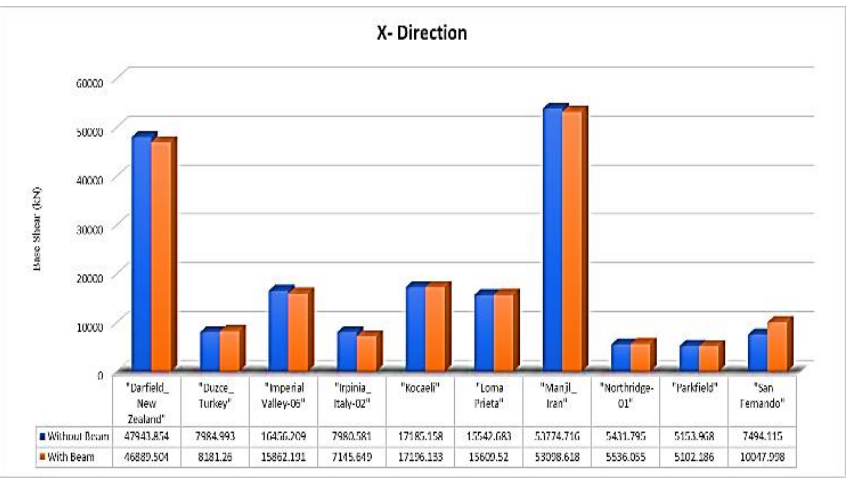

Figure 9. X-Direction Base Shear Values Comparison of the data obtained from both models

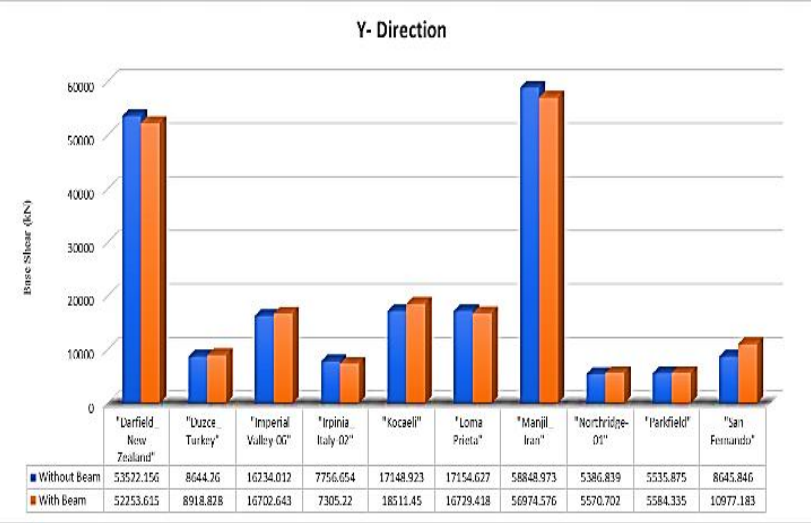

Figure 10. Y-Direction Base Shear Values Comparison of the data obtained from both models

From Figure 9 and Figure, 10 linear decreases of the maximum base shear observed. In the case of a building without beams led to higher base shear. Masonry walls with Beams led to a decrease in maximum base shear. The decrease is $2 \%$ when beams are used, rather than without beam. Similar trends are observed while comparing the drops in shear capacities of models with beam and without beam models. Base shear is 
maximum for the "Manjil Iran" in both the cases with and without bond beam.

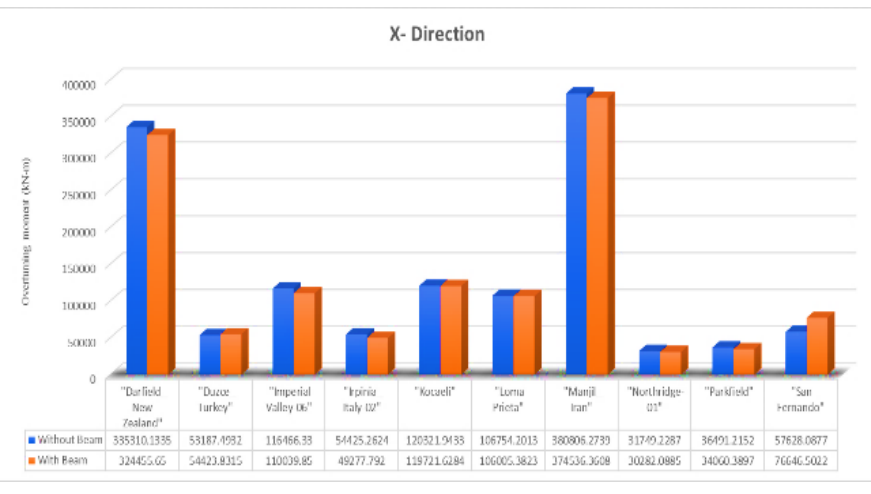

Figure 11. X-Direction Overturning Moment Values Comparison of the data obtained from both models

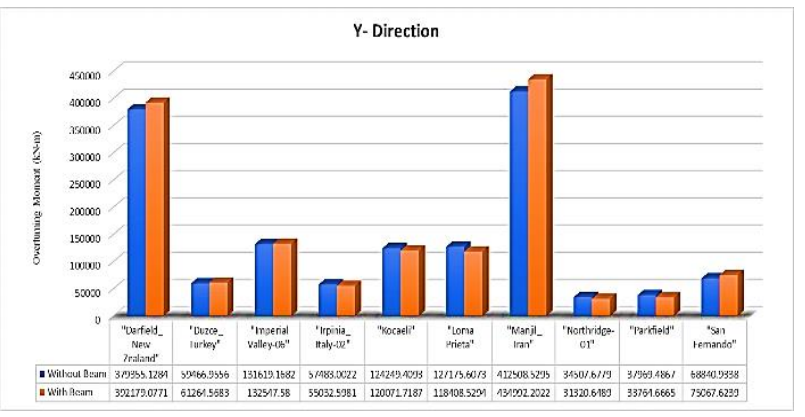

Figure 12Y-- Direction Overturning Moment Values Comparison of the data obtained from both models

The overturning moment has been compared in Figure 11 and Figure 12 below. The figures demonstrate the max influence of the overturning moment of the structure occurred in "manjilIran" for each model and the minimum values were in the Northridge earthquake.

\section{Conclusions and Recommendations}

Two typical types of stone masonry houses are modelled by using SAP version 21. The response of the brick masonry houses to different earthquake time histories is found in terms of top displacement, base shear, and shell stress. The maximum wall stresses under seismic design load were less than the wall strength. The maximum stress was observed at the corner of the opening that justify the importance of the bond beam to confine and strengthen the wall. Also, the maximum drift ratio of the with bond beam was $0.02 \%$ much smaller than the without beam. This means that the adoption of limited wall technology in single house construction, especially in rural areas, can lead to safer buildings with lower construction costs compared to alternative options.

For the rural areas in countries, masonry building with beam can be a real contribution to life protection of the inhabitants, in mitigation of seismic risk, but also as a reconstruction solution after the disaster, because it uses local materials and the construction method is easy to be applied even for nonengineered persons

\section{References}

Banerjee, S., Nayak, S., \& Das, S. (2020). Shear and flexural behaviour of unreinforced masonry wallets with steel wire mesh. Journal of Building Engineering, 30. https://doi.org/10.1016/j.jobe.2020.101254

Brijpuriya R., \& Sharma, A. (2019). Seismic Evaluation of URM Building with Flexible Diaphragm using Nonlinear Static and Nonlinear Dynamic Analysis. International Journal for Research in Applied Science \& Engineering Technology (IJRASET), 48-54. https://1library.net/document/q7wj18kzseismic-evaluation-building-flexible-diaphragm-nonlinearnonlinear-analysis.html

Capozucca, R., Magagnini, E., \& Pace, G. (2018). FE Modelling of Experimental Brickwork Masonry Building Under Eccentric Shear Force. The Open Civil Engineering Journal, 11(1), 1036-1058. https://doi.org/10.2174/1874149501711011036

Ceylan, S., \& Somuncu, M. (2018). Yıl Uluslararası Coğrafya Sempozyumu International Geography Symposium on the 30 th Anniversary of TUCAUM 3-6 October.

Chourasia, A., Singhal, S., \& Parashar, J. (2019). Experimental investigation of seismic strengthening technique for confined masonry buildings. Journal of Building Engineering, 25 , https://doi.org/10.1016/j.jobe.2019.100834

Dutta, S. C., Mukhopadhyay, P. S., Saha, R., \& Nayak, S. (2015). 2011 Sikkim earthquake at eastern himalayas: Lessons learnt from performance of structures. Soil Dynamics and Earthquake Engineering, 75, 121-129. https://doi.org/10.1016/j.soildyn.2015.03.020

Furtado, A., Ramos, T., Rodrigues, H., Arêde, A., Varum, H., \& Tavares, P. (2015). In-plane Response of Masonry Infill Walls: Experimental Study using Digital Image Correlation. Procedia Engineering, 114, 870-876. https://doi.org/10.1016/j.proeng.2015.08.042

Gautam, D., \& Chaulagain, H. (2016). Structural performance and associated lessons to be learned from world earthquakes in Nepal after 25 April 2015 (MW 7.8) Gorkha earthquake. Engineering Failure Analysis, 68, 222-243. https://doi.org/10.1016/j.engfailanal.2016.06.002

Göker, Ş., \& Karaşahin, A. (2015). Depremde hasar gören kırsal yapılar için bir yapısal hasar değerlendirmesi. Dicle Üniversitesi Mühendislik Fakültesi Mühendislik Dergisi, 6(1),

31-38.

https://app.trdizin.gov.tr/makale/TVRrek56WTRPQT09/dep remde-hasar-goren-kirsal-yapilar-icin-bir-yapisal-hasardegerlendirmesi

Gupta, A., \& Singhal, V. (2020). Strengthening of Confined Masonry Structures for In-plane Loads: A Review. IOP Conference Series: Materials Science and Engineering, 936(1). https://doi.org/10.1088/1757-899X/936/1/012031

Korkmaz, S. Z. (2007). Kırsal konutların deprem güvenliğinin arttırılması (Doctoral dissertation, Selçuk Üniversitesi Fen Bilimleri Enstitüsü)

Losanno, D., Ravichandran, N., Parisi, F., Calabrese, A., \& Serino, G. (2021). Seismic performance of a Low-Cost base isolation system for unreinforced brick Masonry buildings in developing countries. Soil Dynamics and Earthquake Engineering, 141, 106501. https://doi.org/10.1016/j.soildyn.2020.106501

Nucera, F., Santini, A., Tripodi, E., Cannizzaro, F., \& Pantò, B. (2012). Influence of geometrical and mechanical parameters 
on the seismic vulnerability assessment of confined masonry buildings by macro-element modeling. In Proceedings of 15th World Conference on Earthquake Engineering, 24-28.

Pinar, U., Nihat, M., Evci, A., \& Ergün, S. (2018). Assessment of Seismic Damage on the Exist Buildings Using Fuzzy Logic. IOP Conference Series: Materials Science and Engineering, 300(1), $\quad 012062 . \quad$ https://doi.org/10.1088/1757$899 X / 300 / 1 / 012062$

Saygilı, Ö. (2020). Se1smic Performance Evaluation of a Masonry Bulding Subjected to Near And Far Field Ground Motions- ProQuest. Civil Engineering Journal, 3. https://www.proquest.com/openview/ba4026522a02b836d47 a12085962236f $/ 1$ ?pq-origsite $=$ gscholar $\&$ cbl $=4665243$

Sharma, A., \& Khare, R. (2016). Pushover Analysis for Seismic Evaluation of Masonry Wall. International Journal of Structural and Civil Engineering Research, 5(3). https://doi.org/10.18178/ijscer.5.3.235-240

Usta, P., Arici, A., Evci, A., \& Kepenek, E. (2017). Sustainability of traditional buildings located in rural area. Periodicals of Engineering and Natural Sciences, 5(2), 231-236. https://doi.org/10.21533/pen.v5i2.136 